\title{
A RE-EXAMINATION OF MALICE AFORETHOUGHT
}

\section{ROLLIN M. PERKINS $\dagger$}

MALICE aforethought is one of the most common watchwords in the homicide cases. Has it a real contribution to offer, or is it merely a euphonious phrase used to conceal the absence of an idea?

In the endeavor to probe for the import of this ancient term, no avenue of approach seems more suitable than an inquiry into what it very clearly does not mean. It does not, for example, indicate either "malice" or "aforethought" in what may be called the face value of these words. "Malice," as it is commonly used in the street, implies hatred, grudge, illwill or spite. But no such notion is incorporated in the expression "malice aforethought." A homicide committed for no purpose other than to satisfy a feeling of hatred or grudge will be murder, ${ }^{2}$ it is true, but this crime may be perpetrated without the slightest trace of personal ill-will. Illustrations of this include the case of a mother who kills her illegitimate offspring to hide her own disgrace, feeling at the time no hatred toward it or any other person and even having the yearnings of a mother's love toward the innocent victim-loving its life just less than her own reputation. ${ }^{3}$ There may be added the suicide pact between the pair whose illicit love was so great as to make death seem preferable to living apart. As a result of this agreement the man, with great reluctance, shot the woman and then turned upon himself the weapon which failed at that time to discharge. ${ }^{4}$ Even more illuminating is the case of the husband who killed his wife at her request, because his love was too great to permit

iProfessor of Law, State University of Iowa; legal adviser to the American Law Institute on Criminal Procedure and on Administration of the Criminal Law.

1. 4 Bl. Conrar. (1897) 198; State v. Jones, 2 Penn. 573, 47 Atl. 1006 (Del. 1900); People v. Lucas, 244 Ill. 603, 91 N. E. 659 (1910); Commonwealth v. Drum, 58 Pa. 9, 15 (1868); McCoy v. State, 25 Tex. 33, 39 (1860).

2. Ellis v. State, 120 Ala. $333,338-9,25$ So. 1, 2-3 (1898). "Malice', in its legal sense, differs from the meaning which it bears in common speech. In common acceptation it signifies ill-will, hatred, or revenge toward a particular individual. Such a condition of mind would, of course, constitute malice in the eye of the law, but such is not necessarily its legal sense." Pembrook v. State, 117 Neb. 759, 763, 222 N. W. 956, 957 (1929).

3. Jones v. State, $29 \mathrm{Ga} .594,607$ (1860).

4. Turner v. State, 119 Tenn. 663, 108 S. W. 1139 (1907). This story by the defendant was not without some evidence to support it, although it was by no means free from doubt. But the court held this to be first degree murder even on his own statement. 
the continuance of her suffering from a hopeless disease. ${ }^{5}$ All of such homicides fulfill every requirement of malice aforethought.

It is perhaps inaccurate to speak of "aforethought" as having any common usage on the street. At its face value, however, it means "thought of beforehand," and the layman uses this phrase to imply the mental process involved where a matter has been pondered over for a substantial period of time in advance. But not even "wilful, deliberate and premeditated malice aforethought" conveys any such message as this to the legal mind. First degree murder can be established on this basis, although the intent to kill is "formed by the accused immediately before the act is actually committed," or "at the very moment the fatal shot was fired." As one court has said: "The act may follow the intent as rapidly as thought may pass through the mind, and if the intent [to kill] be followed by an act which results in the taking of human life with malice aforethought, it is murder in the first degree." It has also been said that a killing may be with malice aforethought although it is done "on the impulse of the moment," or "on the spur of the moment."10 This has led some courts and writers to attribute no meaning whatever to the word "aforethought," as used in this phrase, "inasmuch as the state of mind which causes the act must of necessity precede it,"11 leaving them with the conclusion that "malice" and "malice aforethought" are synonymous terms." In view, however, of the dissimilarity of meaning between "malice aforethought" and "malice" as the latter is used either on the street or in the law in other than homicide cases, ${ }^{13}$ there appears to be adequate reason for keeping the phrase intact. ${ }^{14}$

"Malice," to elaborate a part of the previous statement, is frequently used in the law to mean "the intentional doing of an unlawful act."15 But many such acts are not done with malice aforethought. ${ }^{16}$ Even the

\footnotetext{
5. People v. Roberts, 211 Mich. 187,178 N. W. 690 (1920).

6. Wooten v. State, 104 Fla. 597, 599, 140 So. 474 (1932).

7. State v. Hall, 54 Nev. 213, 13 P. (2d) 624,632 (1932).

8. People v. Weeks, 104 Cal. App. 708, 712, 286 Pac. 514, 515 (1930). See also People v. Russo, 24 P. (2d) 580 (Cal. App. 1933); Maestas v. People, 91 Colo. 36, 11 P. (2d) 227 (1932).

9. Talley v. State, 174 Ala. 101, 106, 57 So. 445,447 (1912).

10. State v. Heidelberg, $120 \mathrm{La} .300,306,45$ So. 256,258 (1908).

11. 3 Stephen, History of Crmitral Law of England (1883) 70.

12. Turner v. Commonwealth, $167 \mathrm{Ky} .365,381,180 \mathrm{~S}$. W. 768,769 (1915).

13. Cribbs v. State, 86 Ala. $613,615,6$ So. 109, 110 (1888).

14. Stephens v. State, 47 Ala. 696 (1872); Brett v. State, 94 Miss. 669, 47 So. 781 (1909);

Cravey v. State, 36 Tex. Cr. App. 90, 35 S. W. 658 (1896).

15. Cribbs v. State, supra note 13.

16. Ibid.
} 
wrongful intention to take human life may fail to meet the legal requirements of this phrase, as where such design is formed in the sudden heat of passion engendered by great provocation. ${ }^{17}$ In fact, even a casual analysis reveals that an intentional homicide may be murder, ${ }^{18}$ or it may be manslaughter ${ }^{10}$ or it may be no crime at all; ${ }^{20}$ that an unintentional homicide may be murder, ${ }^{21}$ or it may be manslaughter, ${ }^{22}$ or it may be no crime at all..$^{23}$ Moreover, malice aforethought is frequently said to be implied. An adequate understanding of the import of "implied malice," however, must be prefaced by an examination into the history of felonious homicide.

\section{I}

Historical Division of Felonious Homicide into Murder and Manslaughter

According to the ancient common law of England, only those homicides were innocent which were caused in the enforcement of justice, ${ }^{24}$ such as the execution of a lawful sentence of death or the "slaying of an outlaw

17. Dye v. State, 127 Miss. 492, 90 So. 180 (1921) ; State v. Wilson, 95 W. Va. 525, 531, 121 S. E. 726, 728 (1924). By statute, what was voluntary manslaughter at common law is sometimes declared to be murder, but this is murder without malice aforethought. Davis v. State, 110 Tex. Cr. App. 605, 607-8, 10 S. W. (2d) 116, 117 (1928); State v. Cooley, 165 Wash. 638, 5 P. (2d) 1005 (1931).

18. This is the typical case of murder with express malice aforethought, if the killing is without justification, excuse or adequate provocation. State v. Fleming, 17 Idaho 471, 493, 106 Pac. 305, 318 (1910).

19. See note 17, supra. "There is a difference between the intent to kill and an intent to murder; and the former may exist when one intends only such killing as amounts to manslaughter." Commonwealth v. Demboski, 186 N. E. 589, 591 (Mass. 1933).

20. "Justifiable or excusable homicide may be committed with a calm, sedate and deliberate mind, and a formed design to kill another." Crook v. State, 27 Tex. App. 198, 242, 11 S. W. 444, 447 (1889).

21. As, for example, where a robber unintentionally kills a.person he was robbing at the point of a gun. McCutcheon v. State, 199 Ind. 247, 155 N. E. 544 (1927) ; Commonwealth v. McManus, 282 Pa. 25, 127 Atl. 316 (1925); State v. Best, 44 Wyo. 383, 12 P. (2d) 1110 (1932).

22. As, for example, the typical case of homicide by criminal negligence. Wright v. State, 166 Ga. 1, 141 S. E. 903 (1928); People v. Buzan, 351 ㅍll. 610, 184 N. E. 890 (1933); State v. Stansell, 203 N. C. 69,164 S. E. 580 (1932) ; State v. Quick, 168 S. C. 76, 167 S. E. 19 (1932).

23. As, for example, the non-negligent killing while performing a lawful act-the typical homicide by misadventure. Commonwealth v. Matthews, $89 \mathrm{Ky} .287,12$ S. W. 333 (1889); State v. Turnage, 138 N. C. 566,49 S. E. 913 (1905). "The statute protects the appellant if he committed the homicide by accident or misfortune (a) in 'doing any other lawful act by lawful means, with usual and ordinary caution, and without unlawful intent. . . " State v. Welch, 25 P. (2d) 211, 214 (N. M. 1933).

24. 2 Pollock and Martiand, History of ENGLisH LaW (1895) 476. 
or a hand-having thief or other manifest felon who resists capture."26 These killings were justifiable ${ }^{26}$ and the slayer was entitled to an acquittal if brought to trial. He who had caused the death of another by misadventure or in the necessary defense of his own life ${ }^{27}$ or while he was of unsound mind $^{28}$ had no legal defense. In 1203, for example, Robert of Herthdale, arrested for having in self-defense slain a madman who had previously killed five men in hic insane fury, was not acquitted on this ground, but was retained in custody, "for the king must be consulted about this matter."' And in 1214 Roger of Stainton, who had killed a girl by accident, was spared only by a royal pardon. ${ }^{30}$ Such cases, let it be emphasized, called originally for a special act of grace, for "the king himself must decide in each case whether life and limb shall be spared." And the royal pardon, while it saved the slayer's life, did not shield him from the forfeiture of his goods." "In early days 'there could be little law about this, for all depended upon the king's grace," "33 but later the rule changed and such a pardon was granted by the chancellor as a matter of course without referring the matter to the king. ${ }^{34}$ Homicides which entitled the slayer to a pardon, even though they resulted in conviction and forfeiture of goods, were spoken of as having been committed "without felony"35 - they were pardonable or "excusable." Later the procedure changed, partly with the aid of legislation, ${ }^{37}$ and evidence of excusable self-defense, for example, disproved the charge itself and entitled the accused to an acquittal. ${ }^{38}$

25. Ibid.

26. 2 Holdsworte, History of ENGLish LAw (1926) 358.

27. "The man who commits homicide by misadventure or in self-defence deserves but needs a pardon." 2 Pollock and MartlaNd, op. cit. supra note 24, at 477 . "We do not think that in the thirteenth century a homicide in self-defence would have been justifiable, even though it was perpetrated in the endeavor to prevent a felony." Ibid. $\mathbf{n} .3$.

28. Id. at 478 .

29. 1 Selden Society, Select Pleas of the Crown (1887) No. 70.

30. Ibid.

31. 2 Pollock and Maitland, op. cit. supra note 24 , at 481 .

32. 3 Holosworth, op. cit. supra note 26 , at 312 .

33. Id. at 313, quoting 2 PoLLOCK AND MAIILAND, op. cit. supra note 24 , at 483 .

34. Note, Fitz Herbert, Corone (1329) 361.

35. 2 Pollock and MaItland, op. cit. supra note 24 , at $483 ; 3$ Holdsworth, op. cit. supra note 26, at 312. Roger of Stainton, for example, was said to have killed by misadventure and "not by felony" although the royal pardon was needed to spare his life. 1 SeLden Society, op. cit. supra note 29 , No. 114.

36. 3 HoldsworTe, op. cit. supra note 26 , at 311 .

37. 24 HEN. VIII, c. 5 (1532).

38. ANon. Y. B. TrIn. 26 HeN. VIII, f. 5, pl. 21 (1534). 
Thus the early common law, with good and sufficient reason, ${ }^{39}$ grouped the homicide cases as follows: (1) justifiable, (2) excusable, and (3) felonious. Moreover, it knew but one degree of felonious homicide, ${ }^{40}$ if the additional torture provided for traitors be ignored. ${ }^{41}$ In other words all homicide which was not justifiable or excusable was felonious. The word "murdrum" or "murder" (at one time reserved for secret slayings) ${ }^{42}$ came to be applied to the more serious forms of felonious homicide (which perhaps had long been the popular meaning), ${ }^{43}$ but this was largely a matter of mere terminology. Every felonious killing was punishable by death, ${ }^{44}$ whether it amounted to murder or not, while on the other hand it was within the benefit of clergy even if it was murder of the most atrocious nature. ${ }^{45}$ Hence it was of very little practical importance whether a criminal homicide merited the label "murder" or not. ${ }^{46} \mathrm{He}$ who was convicted of felonious homicide might suffer death, or he might escape with branding and a short term of imprisonment. Whether the penalty in a particular case was one or the other depended, not upon the circumstances of the killing, but solely upon the qualifications of the

39. If the distinction between justifiable and excusable homicide is to be retained in modern law, the difference should certainly be grounded upon other than purely historical reasons. One who kills another in self-defense, under circumstances in which he was privileged by law to make use of deadly force to save his own life, should be said to have committed justifiable homicide (in spite of the fact that it was originally excusable only) because what is authorized by law is in every proper sense, justified. But one who kills another by accident may, under certain circumstances, be excused, but cannot properly be said to be justified.

40. 2 Pollock aNd MatTLAND, op. cit. supra note 24 , at 484.

41. Ibid. "In the first place I may observe that murders of a particular class were separated from other cases of homicide by being classified as petty treason." 3 STEPHEN, op. cit. supra note 11 , at 34 .

42. "And first of murder, which anciently signified only the private killing of a man, for which by force of a law introduced by King Canutus for the preservation of his Danes, the town or hundred where the fact was done, was to be amerced to the king, unless they could prove that the person slain were an Englishman, (which proof was called Engleschire), or could produce the offender, etc." 1 Hawk. P. C. (1824) c. 31, § 1. See also Bracton, DE LEGIBUS, $134 \mathrm{~b}$.

43. 2 Pollock AND MaITLAND, op. cit. supra note 24, at 486.

44. "The outlaw forfeits all, life and limb, lands and goods. ... The Conqueror would have no one hanged; emasculation and exoculation were to serve instead. . . Very slowly in the course of the thirteenth century the penalty of death took the place of mutilation as the punishment due for felons-and this without legislation." 2 PorLOCK AND MAITLAND, op. cit. supra note 24 , at $459-60$.

45. "Up to this time . . . all homicide, unless it was justifiable, se defendo or by misadventure, was felonious and so punishable by death, and was also within benefit of clergy whether it did or did not amount to murder." 3 STEPHEN, op. cit. supra note 11 , at 44 .

46. The only distinction seems to have been that murder was not within the terms of any general pardon. Ibid. 
slayer. It was the general expansion of benefit of clergy, together with statutes, that withdrew certain specific offenses from its protecting influence, which drew the line between murder and manslaughter.

The harsh severity of the early English law was alleviated to some extent by various devices resorted to by the judges for this purpose. Among these may be mentioned an ultra-technical interpretation of the rules of criminal procedure and of substantive criminal law (the effects of which still handicap the administration of justice), ${ }^{47}$ together with an equally absurd liberality in recognizing the privilege known as "benefit of clergy." It is the latter with which we are here concerned. In ancient times the lay courts did not have criminal jurisdiction over the clergy in felony cases. ${ }^{48}$ The members of the clergy could be tried only in the ecclesiastical court and could be punished only by such penalty as that court could inflict." It was an "elementary rule that the church would never pronounce a judgment of blood," change in the procedure, ${ }^{61}$ the chief characteristic of benefit of clergy was that it shielded those who qualified for its protection from the capital part of the punishment ${ }^{52}$ which was otherwise a necessary consequence of felony convictions.

The manner in which benefit of clergy was used to mitigate the bloodthirsty demands of the early law was through an extension of it altogether beyond its proper boundaries. Whereas originally "the only persons who could claim the privilege were ordained clerks, monks and nuns," courts later extended it to include every man who could read. ${ }^{54}$ Under relatively early statutory provisions which prevailed until 1779 , the convicted felon who escaped the death penalty by benefit of clergy was (unless he was a peer or a clerk in orders) branded in the hand and subjected to imprisonment for a term not exceeding one year. ${ }^{65}$ The net

47. As Justice Holmes said (in a larceny case): "This distinction is not very satisfactory, but it is due to historical accidents in the development of the criminal law, coupled, perhaps, with an unwillingness on the part of the judges to enlarge the limit of a capital offence." Commonwealth v. Ryan, 155 Mass. 523, 30 N. E. 364 (1892).

48. 3 Holdsworte, op. cit. supra note 26 , at $294 ; 1$ STEPHEN, op. cit. supra note 11, at 459.

49. 1 PorIock AND MaIILAND, op. cit. supra note 24, at 424.

50. Id. at 427 .

51. Id. at $437-440$.

52. 3 HoLdswORTH, op. cit. supra note 26 , at 298-9.

53. Id. at 296. There "seems no reason for doubting that nuns were entitled to the same privilege, though, to their credit be it said, we have in our period found no cases which prove this." 1 Pollock AND MaItLaNd, op. cit. supra note 24, at 428 .

54. 1 StEPHEN, op. cit. supra note 11, at 461 . It required a statute to extend the privilege to women. 4 WIIL. \& MARY, c. 9 (1692).

55. 1 STEPREN, op. cit. supra note 11 , at $462-3$. The provision for branding was added 
result of this device for alleviating the severity of the penal law was that of two persons convicted of the same felony one might be hanged while the other was branded and imprisoned for a short term, due solely to the fact that the latter could read whereas the former could not. That this was ultimately changed by statute is more readily understandable than the long delay in accomplishing this end. ${ }^{50}$

The first step in correcting this absurd distinction between defendants who could read and those who were illiterate was an exclusion of certain felonies from the protecting influence of benefit of clergy. ${ }^{57}$ The next was the removal of the necessity for reading as a qualification for this benefit. ${ }^{58}$ The result of these two moves was that all felonies were divided into two classes, those that were "clergyable" and those that were not. Persons convicted of "clergyable" felonies were not punished capitally, even if they were illiterate, whereas ability to read no longer saved the life of one who had been convicted of a felony which the statute declared to be "without benefit of clergy."

Such a development could not but have an important bearing upon the law of homicide. A series of statutes, during the period from 1496 to $1547,{ }^{, 0}$ excluded from benefit of clergy certain of the more serious forms of felonious homicide, referring to them as murder committed with malice aforethought (malice prepensed) ${ }^{61}$ The result of these statutes

by statute in 1487 ( 4 HEN. VII, c. 13) and that for imprisonment not to exceed one year in 1576 (18 EIIz. c. 7, §§ 2, 3).

56. "Till 1487 any one who knew how to read might commit murder as often as he pleased, with no other result than that of being delivered to the ordinary to make his purgation, with the chance of being delivered to him 'absque purgatione.' That this should have been the law for several centuries seems hardly credible, but there is no doubt that it was. Even after 1487 a man who could read could commit murder once with no other punishment than that of having $M$ branded on the brawn of his left thumb ..." 1 STEPHEN, $o p$. cit. supra note 11 , at $463-4$.

57. To speak of this as a "step" is figurative only, since it resulted in a long series of statutes. The matter was considerably overdone. Thus Blackstone lamented the existence in his day of one hundred and sixty "felonies without benefit of clergy." $4 \mathrm{Br}$. Conns. (1897) 18.

58. 5 ANNE C. 6 (1705). The privilege had been extended to women by statute in 1692. See note 54, supra.

59. The statutory provision is frequently spoken of in this form. See, for example, 4 BL. Cosnar. (1897) 18. The statutes themselves spoke in some such terms as that one convicted, etc. "shall not be admitted to have or enjoy the privilege or benefit of clergy or sanctuary, but shall be put from the same. ..." 1 EDw. VI, c. 12, § 10 (1547).

60. 12 HEN. VII, c. 7 (1496); 4 HEN. VIII, c. 2 (1512); 23 HEN. VUI, c. 1, \$§ 3, 4 (1531); 1 EDw. VI, c. 12, § 10 (1547).

61. The expressions used are such as "wilful prepensed murders," "prepensedly murder" (12 HEN. VII, c. 7 (1496); "murder upon malice prepensed" (4 HEN. VIII, c. 2 (1512); 
was to divide felonious homicide into two main categories depending upon whether or not the killing was committed with malice aforethought. If it was with malice aforethought the punishment was death and the offense was called "murder"; if it was without malice aforethought it was punished by a brand upon the brawn of the thumb and imprisonment not to exceed a year. ${ }^{62}$ The word "manslaughter" was adopted to describe this lesser grade of felonious homicide. ${ }^{63}$

II

\section{Early Meanings of Malice Aforethought}

The phrase "malice aforethought," however, had made its appearance in the law long before this legislation had put certain types of felonious homicide beyond the protection of benefit of clergy. But strangely enough, its original meaning was altogether different from that with which it was used in these statutes. For example, in 1329 , the jurors, in bringing in a verdict of conviction ${ }^{64}$ of excusable homicide, included in their finding - in order to entitle the defendant to a pardon-that he had killed the deceased "in self-defence, and not by felony or of malice aforethought." Mos Moreover, the patent rolls of Henry III point to this as a common formula in pardons granted in the 1200's to those who had committed homicide by misadventure, in self-defense or while of unsound mind. For example: "Whereas our justices in their eyre in such a county have informed us . . . that Nicholas of Frackenham slew Roger of Mepham by misadventure and not by felony or malice afore-

\footnotetext{
"wilful murder of malice prepensed" (23 HEN. VIII, c. 1 (1531) ; "Murder of malice prepensed" (1 EDw. VI, c. 12 (1547).

62. Until 1705 when the requirement of reading was removed as a qualification for benefit of clergy (see note 58, supra), an illiterate convicted of manslaughter was capitally punished.

63. Staunford distinguishes between homicide "par chance medley" and "par voy de murder." Staunford, Plees Del Coron (1560) 19 A.

". . felonious homicide, which is not murder, came to be known as homicide by chancemedley, and, later still, as manslaughter." 3 HoxdSwortr, op. cit. supra note 26, at 314 .

"This distinction between murder and manslaughter only, is occasioned by the statute of 23 H. 8 and other statutes that took away the benefit of clergy from murder committed by malice prepensed, which statutes have been the occasion of many nice speculations." Regina. v. Mawgridge, Kel. 119, 121 (1707).

In 1553 it was held that one indicted for murder could be convicted of manslaughter. Matters of the Crown Happening at Salop, 1 Plow. 97, 101 (1553).

64. The defendant was not acquitted but was "remitted to prison to wait for the mercy of the king," according to the practice of that time.

65. Anonymous, FITZ HERBERT, op. cit. supra note 34, at 284. Translated in 3 StEPHEN, op. cit. supra note 11, at 39 .
} 
thought-or that William King killed Ralph de le Grave in self-defence and not of malice aforethought-or . . . that Maud who is in prison for slaying her two sons killed them in a fit of madness and not by felony or malice aforethought ... now we have pardoned," and so forth. ${ }^{66}$

Thus the former function of this phrase seems to have been to distinguish homicides which were felonious from those which were excusable. As so used it seems to mean little more than intentional wrongdoing, ${ }^{67}$ with in fact no strong emphasis on the intention other than to exclude harm by misadventure. ${ }^{\text {ss }}$ Bearing in mind the fact that before the period of these statutes the word "murder" had come to refer to some of the more serious forms of felonious homicide, while the phrase "malice aforethought" seems to have covered all forms, one might be led to the conclusion that it was "murder" rather than "malice aforethought" which was employed for the purpose of distinguishing the felonious homicides that were to be put beyond the reach of benefit of clergy, from those that were left upon their former footing. The language of the statutes, however, fails to support such an inference. ${ }^{69}$ Apparently it was homicide by waylaying which was the particular object of this legislative attention, ${ }^{70}$ and the word aforethought (prepensed) was there used in the sense of a design meditated upon for a substantial period of time in advance. Perhaps the most illuminating decision on this point is to be found just a few years after the last of these statutes was enacted. The statute of Edward VI, ${ }^{71}$ which was the broadest of the group, was passed in 1547. In 1553 it was held that if four persons joined in killing

66. 2 Pollock art Martland, op. cit. supra note 24 , at 478 .

67. "When we first meet with malice prepense it seems to mean little more than intentional wrong-doing. ..." Id. at 467 .

68. Ibid. note.

69. The first of the group (12 Hear. VII, c. 7 (1496)) does not use this phrase but speaks of "prepensedly murder." See also the second (4 HEN. VIII, c. 2 (1512)) which presents three categories, in only one of which "malice prepensed" appears.

70. "If we are right, the guet-apens which in modern French law raises a mere meatre to the dignity of an assassinat, is first cousin to the malice aforethought which characterizes our English murder; both go back to days when waylaying is a specially heinous crime and a cause for royal interference." 2 Pollock AND MaItLAND, op. cit. supra note 24, at 467, n. 2. "In 1270 the Earl of Warenne and Alan de la Zouche were litigating before the justices in Westminster Hall. From words they came to blows and Warenne's retainers grievously wounded Alan so that after a while he died. Warenne was allowed to make his peace on paying 5000 marks to the king and 2000 to the wounded man and on swearing with fifty compurgators that the deed was done 'non ex praecogitata malitia ... sed ex motu iracundiae nimis accensae.' Here we already have the contrast between 'malice aforethought' and a 'sudden falling out'; but apparently we have rather an act of grace than a judicial sentence." 2 POLIOCK AND MATTLAND, op. cit. supra note 24 at 484, n. 2.

71. 1 EDw. VI, c. $12, \S 10$ (1547). 
a man, three of them having planned the homicide in advance, while the fourth joined them on the spur of the moment because he happened to be present, the three were guilty of murder, while as for the other this was "manslaughter in him, and not murder, because he had not malice prepense."72 Moreover, Lambard, writing in $1581,{ }^{73}$ uses malice aforethought in the sense of real and substantial premeditation. He does not require direct and positive evidence of the well-laid plan in every case. In fact, even in his writings are to be found seeds of the influences which were eventually to whittle away every trace of the time element of malice aforethought. But the starting point seems to be a rather reasonable inference of fact-that a killing without any apparent motive must have been due to a concealed motive. Hence he says that in case of an intentional killing without apparent provocation, the law judges the fatal act "to have proceeded of former malice meditated within his owne minde, howsoever it bee kept secret from the sight of other men."74

\section{III}

\section{"Express" and "Implied" Malice}

It is at this point that we find the origin of "express malice" and "implied malice," terms whose meanings have shifted during the change of import of the basic phrase itself. The classic definition of the former is this: "Express malice is when one, with a sedate deliberate mind and formed design, doth kill another: which formed design is evidenced by external circumstances discovering that inward intention; as laying in

72. Matters of the Crown Happening at Salop, supra note 63, at 100 . The following statement in this case is important: ". . . if he kills them to whom he had before-hand intended to offer such violence..."The absence of any trace of provocation is noteworthy. In fact, when the element of provocation is first introduced, its importance is merely because it points to the killing as a sudden occurrence rather than the result of a well-laid plan.

". . . the law shall adjudge it to be upon that sudden occasion and stirring of blood, being also provoked at the sight of his son's blood, that he made that assault, and will not presume it to be upon any former malice, unless it be found." Royley's Case, Cro. Jac. 296 (1612) (italics added). See also Rex v. Mawgridge, 12 Co. Rep. 87 (1611). The modern rule of provocation as a concession to the weakness of human nature was a later development. "There is no difference between murder, and manslaughter; but that the one is upon malice aforethought, and the other upon a sudden occasion . . " 3 Co. INst. (1797) 55 .

73. William Lambard, 1536-1601. His Eirenarcha was published in 1581. See 4 HordsWORTH, $o p$. cit. supra note 26 , at 118 .

74. Ladabard, Etrenarcha (1619) 239. He also expresses the same idea in this form: "So, many times the law doth (by the sequelle) judge of that malice which lurked before within the partie, and doth accordingly make imputation of it." Ibid. 
wait, antecedent menaces, former grudges, and concerted schemes to do him some bodily harm." 75 And Coke speaks of "malice fore-thought, either expressed by the party or implied by law."76 "The words "express or implied," " said one court, "add nothing to the meaning of the word 'malice'. They do not imply different kinds of malice, but merely the manner in which the only kind known to the law may be shown to exist, - that is, either by positive evidence or by inference."'77

The notion that one who killed a man whom he had intended only to rob, was guilty of murder had made its appearance in the days of Lambard, and was explained by him on the ground that the law "implyeth a former malicious disposition in him rather to kill the man, than not to have his money from him." 78 This does not carry conviction as an inference of fact. It falls distinctly into the field of fiction, by which there is imputed to a man a state of mind which was not actually present. ${ }^{79}$ On this cornerstone is laid the foundation for quite a different meaning for the words "express" and "implied," as qualifying the phrase "malice aforethought," and there begins to appear, thinly camouflaged by fiction for a time, the recognition of an actual difference in the states of mind represented by these two terms. The distinction could not escape the attention of Hale who referred to them as malice in fact, and malice in law. ${ }^{80}$

For a time the fictitious formula prevailed. An intent to kill or injure was required for malice aforethought; but in certain cases, such as the robber who killed his victim by accident during the attempt to rob him, the slayer was conclusively presumed to have had such an intent. ${ }^{81}$ This

75. 4 Br. Cosar. (1897) 199.

76. 3 Co. Isst. (1797) 47 (italics added).

77. State v. Milam, 88 S. C. $127,130,70$ S. E. 447,449 (1910). This is one of the best statements of the ancient view, but does not picture the general notion at the time of this case.

78. LAMCBARD, op. cit. supra note 74 , at 241 .

79. "First, malice prepense is half accidentally made the test of murder. It is then defined to mean a deliberate premeditated design to kill or hurt. This being found too narrow a definition, it is enlarged by the remark that killing without apparent provocation raises a presumption in fact of concealed motive. This being still too narrow, the presumption, in fact, becomes a presumption of law applying to all cases of unprovoked killing, even if, in fact, premeditation is disproved." 3 STEPHEN, op. cit. supra note 11, at 63.

80. "Such a malice therefore, that makes the killing of a man to be murder, is of two kinds, 1 Malice in fact, or 2 Malice in law, or ex praesumptione legis. Malice in fact is a deliberate intention of doing some corporal harm to the person of another." 1 HALE $P . C$. (1847) 451.

81. "This implication of a species of malice which did not exist seems to have been invented for the purpose of bringing cases of constructive murder, so called, within what was supposed to be the legal definition of the crime. It was evidently supposed . . . that the phrase, malice aforethought, used in indictments for murder, necessarily imputed a 
could not conceal the fact that the malice "implied" in such a case had reference to a different psychical element than the actual intent to cause death or bodily harm, and in the course of generations judges tended more and more to override the fiction and to recognize frankly that there may be malice aforethought without any design to kill or injure. ${ }^{82}$

The terms "express malice aforethought" and "implied malice aforethought," as now used, are the accidental result of a long series of decided cases. They have tended much to confuse the law of felonious homicide. If one single contribution of value has been made by them it remains as yet undiscovered. But they cannot be ignored because of their frequent appearance in legal literature. The common law felt no particular urge to define them with precision because the crime and the punishment were the same whichever label was applied. Hence the lack of uniformity of definition need occasion no surprise.

"Express malice aforethought," for example, will be found to have four different meanings in different jurisdictions, even if occasional reversions to the ancient usage be ignored. ${ }^{83}$ These differences result from disagreement as to whether the phrase is limited to an intent to kill or includes also an intent to inflict great bodily injury, and whether it is limited to an intent which was directed against the very person who was killed or includes an intent to inflict such harm upon another. Thus express malice aforethought has been said to mean (assuming the absence of justification or excuse or any mitigating circumstance sufficient to reduce the homicide to manslaughter): (1) an intent to kill the very person killed; ${ }^{84}(2)$ an intent to kill the very person killed or to inflict

charge of premeditated design to kill. To meet this averment, which in cases of constructive murder was not required to be proved, the law was said to imply, that is, to supply by mere fiction, the requisite degree of malice. There was, however, in truth not the slightest necessity for this fiction; the interpretation of the word malice, on which it was founded, being entirely erroneous." Darry v. People, 10 N. Y. 120, $138^{\circ}$ (1854).

82. Wright v. State, 166 Ga. 1, 141 S. E. 903 (1927); People v. Hartwell, 341 Il. 155, 157,173 N. E. 112, 113 (1930); McCutcheon v. State, supra note 21 , at 257,155 N.E. at 548; State v. Johnson, 211 Iowa 874, 879, 234 N. W. 263, 266 (1931); State v. Sanderson, 169 La. 55, 61, 124 So. 143, 146 (1929); Commonwealth v. Madeiros, 255 Mass. 304, 315, 151 N. E. 297, 300 (1926); State v. Glover, 330 Mo. 709, 50 S. W. (2d) 1049 (1932); People v. Jernatowski, 238 N. Y. 188, 144 N. E. 497 (1924); State v. Best, supra note 21.

83. For a case in which it is said to refer not to the state of mind but only to the manner of proof, see State v. Milam, supra note 77.

For the view that express malice aforethought refers to a preconceived plan, see Anthony v. State, 21 Miss. 263, 264 (1850). Compare State v. Prettyman, 6 Boyce 452, 455-6, 100 Atl. 476,478 (Del. 1917).

84. If defendant with a sedate mind and formed design was attempting to kill Scroggins, and in that attempt killed Martha Gray without intending to do so, this homicide cannot be murder in the first degree because it was "not with express malice to the party killed." Ferrell v. State, 43 Tex. 503 (1875). See also State v. Fleming, supra note 18. 
great bodily injury upon him; ${ }^{85}$ (3) an intent to kill some person; ${ }^{86}$ (4) an intent to cause death or great bodily injury to some person. ${ }^{87}$ It is with the phrase "implied malice aforethought," however, that the chief difficulties are encountered. During its metamorphosis from a mere inference of fact to a presumption of law and finally to its frank recognition as a psychical fact distinct from "express" malice, no one of these meanings was, unfortunately, entirely lost, and at the present time the term is tainted with all three.

Malice aforethought is a "subjective condition of the mind, discoverable only by words and conduct."ss And since it often happens that one who is acting wrongfully does not put his actual purpose into words, it is frequently necessary for this "to be inferred from acts committed." If, for example, one person should load a revolver, deliberately aim it at another at close range, and shoot him through the heart, his intent to kill or inflict great bodily injury would be rather convincingly indicated. This is not a peculiarity of procedure, but an inference of fact which would be drawn outside of the court room as readily as in the trial of a case. In either place, moreover, it might be overcome by further facts. If it could be shown, for instance, that the deceased was wearing at the time a vest supposed to be bullet-proof, and that the shooting was merely for the purpose of demonstrating the protective qualities of the garment, the inference of an intent to kill would disappear. ${ }^{90}$ In the absence of this, or some other satisfactory explanation of such conduct, the inference would remain, and the term "implied malice" is frequently used in speaking of such a situation. ${ }^{.1}$ The confusing effect of this use of the phrase may be emphasized by pointing out that the malice aforethought which is "implied" in this sense (inferred as a matter of fact from the

55. ". . . a sedate, deliberate mind and formed design to take the life of, or to do some great or serious bodily injury to the person killed." State v. Faino, 1 Marv. 492, 501, 41 Atl. 134, 135 (Del. 1894). See also Farrer v. State, 42 Tex. 265 (1875).

86. "Express malice is that deliberate intention unlawfully to take away the life of a fellow creature." People v. Cochran, 313 ㅍl. 508, 518, 145 N. E. 207, 211 (1924).

87. "Malice express, is a design formed of taking away another man's life, or of doing some mischief to another, in the execution of which design death ensues." Rex v. Oneby, 2 Ld. Raym. 1485, 1489 (1727). See also State v. Brown, 4 Penn. 120, 124, 53 Atl. 354, 355 (Del. 1902).

S8. State v. Hamrick, 112 W. Va. $157,166,163$ S. E. 868, 873 (1932).

89. Stevens v. State, 42 Tex. Cr. App. 154, 173, 59 S. W. 545, 549 (1900).

90. Whether this would or would not be criminal negligence does not concern us here.

91. See, for example, Kennedy v. State, 85 Ala. 326, 332, 5 So. 300, 302 (1888); Jacobs v. State, 28 Tex. App. 79, 82, 12 S. W. 408, 409 (1889); Martinez v. State, 30 Tex. App. 129, 137, 16 S. W. 767, 768 (1891); State v. Cassim, 112 W. Va. 92, 97, 163 S. E. 769, 771 (1932). 
acts of the slayer) is "express" in another sense (the psychical fact thus found being an intent to kill the person slain).

To avoid this confusion the word "implied" should be rejected when an inference of fact is intended. The word "inferred" seems most appropriate for this purpose and has frequently been so employed by the courts. ${ }^{92}$ Other forms of expression may be adopted without objection, such as the following: "The deliberate selection and use of a deadly weapon is a circumstance which indicates a formed design to kill, in the absence of evidence showing a contrary intent." "presumed," however, which has found considerable favor with the courts in this connection, should not be employed to indicate an inference of fact. A true presumption is a rule of evidence which calls for a certain result as far as the particular case is concerned, unless the party adversely affected by the presumption comes forward with evidence to overcome it. To use the term "presumption" in the sense of "inference" or probative significance, is a misuse of the word. ${ }^{94}$

Mention of this misuse is warranted because one of the common exploitations of the phrase "implied malice" involves a presumption in the true sense of the word-sometimes spoken of as a "presumption of law" to distinguish it from the misnamed "presumption of fact." "95 It would be an unreasonable burden upon the prosecution to require it in every murder case to prove not only the killing of the deceased by the defendant, but also the non-existence of every conceivable set of circumstances which might be sufficient to constitute either innocent homicide or guilt of manslaughter only. Thus the state is not required, in order to make out a prima facie case of murder, to prove (in addition to the killing of the deceased by the defendant) that the defendant was not so insane as to be wanting in criminal capacity, ${ }^{96}$ or that the killing was not an accident, or that it did not result from the privileged use of deadly force ${ }^{97}$ or that it did not result from the sudden heat of passion engendered by great provocation, or other matters of this kind. To require

92. McAndrews v. People, 71 Colo. 542, 208 Pac. 486 (1922); State v. Decklotts, 19 Iowa 447, 449 (1865); Stevens v. State, supra note 89, at 157, 59 S. W. at 547; Evans v. Commonwealth, 170 S. E. 756, 762 (Va. 1933); State v. Wilson, 95 W. Va. 525, 121 S. E. 726 (1924).

93. State v. Galvano, 34 Del. 409, 419, 154 Atl. 461, 465 (1930) (italics added).

94. 5 WIGMIORE, EvIDENCE (2d ed. 1923) § 2491.

95. "There is in truth but one kind of presumption; and the term 'presumption of fact' should be discarded as useless and confusing." Ibid.

96. State v. Silverio, 79 N. J. L. 482,488 , 76 Atl. 1069, 1071 (1910).

97. Triplett v. Commonwealth, $245 \mathrm{Ky}, 167,53 \mathrm{~S}$. W. (2d) 345 (1932); McGee v. State, 144 So. 112 (Ala. 1932). 
such proof, moreover, would constitute an absurd waste of time..$^{98}$ This difficulty is avoided by a rule of law in the form of a presumption. It has sometimes been said that every homicide is presumed to be with malice aforethought and that it devolves upon the prisoner to prove circumstances which will justify, excuse or mitigate the act. ${ }^{99}$ This, however, is quite generally recognized to be an overstatement of the position. If the evidence introduced by the state, while showing the killing of the deceased by the defendant, should at the same time establish some basis of justification or excuse, the defendant would be entitled to a directed verdict of acquittal without the introduction of evidence on his part. ${ }^{100}$ Hence it is necessary to put the matter in this form: Every homicide is presumed to have been committed with malice aforethought "unless the evidence which proves the killing itself shows it to have been done without malice."101 Since this is a presumption in the true sense it merely places upon the defendant the burden of going forward with the evidence. ${ }^{102}$ It is rebuttable and may be overcome by evidence which throws a different light upon the situation ${ }^{103}$ or which establishes exculpating or mitigating circumstances. ${ }^{104}$ If no such evidence is offered, a conviction of murder is proper because of the "presumed malice."

98. "Trials would be made even more unnecessarily long than they are if all possible defenses of this sort had to be met in advance without waiting to see whether they are set up." Per Holmes, C. J., in Commonwealth v. Chance, 174 Mass. 245, 250, 54 N. E. 551,554 (1899).

99. See, for example, the instruction of the trial judge in McDaniel v. State, 16 Miss. 401,417 (1847). This was held by the higher court to be "too broad and unrestricted." Sometimes such presumption is said to be limited to homicides committed with a deadly weapon. State v. Benson, 183 N. C. 795, 799, 111 S. E. 869, 871 (1922).

100. The burden is always upon the state to rebut exculpatory evidence contained in its own case. State v. Copenbarger, 52 Idaho 441, 16 P. (2d) 383 (1932); State v. Gregory, 203 N. C. 528, 166 S. E. 387 (1932).

101. Murphy v. State, 37 Ala. 142, 144 (1861).

". . when the state has proved the commission of a homicide by a defendant, the presumption is that he is guilty of either murder in the first or second degree, unless the proof offered by the state itself tends to reduce the offense to manslaughter or show that the defendant was justifiable or excusable." Miranda v. State, 26 P. (2d) 241, 243 (Ariz. 1933).

102. 5 WIGMrore, loc. cit. supra note 94.

103. Mann v. State, 124 Ga. 760, 762, 53 S. E. 324, 325 (1906); State v. Cassim, supra note 91.

104. We "may take it for a general rule that all homicide is malicious, and of course amounts to murder, unless where justified, . . . excused . . . or alleviated into manslaughter . . . and all these circumstances of justification, excuse or alleviation it is encumbent upon the prisoner to make out to the satisfaction of the court and jury. . . ." 4 BL. Connr. (1897) 201. See also Stepp v. State, 170 Ark. 1061, 1067, 282 S. W. 684, 687 (1926); Wallen v. Commonwealth, 134 Va. 773, 784, 114 S. E. 786, 790 (1922); State v. Wilson, supra note 92, at 581, 121 S. E. at 729; State v. Cassim, supra note 91. "Proof 
"Implied malice," in addition to being employed where the idea intended could be conveyed to better advantage by (1) "inferred malice" and (2) "presumed malice," has also a third usage. In this sense it is used to cover such part of the field of malice aforethought as is not included within the term "express malice."105 And just as "express malice" may have any one of four meanings, depending upon whether the user does not include (within the intent to kill) the intent to inflict great bodily injury, and whether he does or does not include an intent directed at some person other than the one killed, so "implied malice," when used to complement that term, has four corresponding variations.

\section{IV}

\section{Intent to Kill or to Inflict Great Bodily Injury}

At this juncture, putting carefully to one side "inferred malice" and "presumed malice," as terms which make important contributions to the law, the phrases "express malice" and "implied malice" should be eliminated from consideration. This will permit undivided attention to be directed to malice aforethought itself. There need be no hesitation in saying that malice aforethought is present whenever-in the absence of justification, excuse or some special circumstance of mitigation-there is an intent to kill ${ }^{106}$ or to inflict great bodily injury, ${ }^{107}$ regardless of whether this intent is focused upon the person who is actually killed or upon some other. ${ }^{108}$ One, for example, who maliciously shoots at an enemy and happens to kill a friend, is guilty of murder. ${ }^{109}$

Reference to the intent to inflict great bodily injury requires further attention. The ancient writers seem to have made no distinction based upon the degree of bodily force intended to be inflicted. Lambard (whose Eirenarcha appeared shortly after the legislative division of felonious

or admission of an intentional killing with a deadly weapon raises two presumptions against the killer: First, that the killing was unlawiul; and, second, that it was done with malice. This is murder in the second degree." State v. Bailey, 205 N. C. 255, 171 S. E. 81 (1933).

105. See, e.g., State v. Galvano, 34 Del. 409, 154 Atl. 461 (1930).

106. State v. Pasour, 183 N. C. 793, 111 S. E. 779 (1922).

107. State v. Calabrese, 107 N. J. L. 115, 151 Atl. 781 (1930); Commonwealth v. Marshall, 287 Pa. 512, 135 Atl. 301 (1926).

108. State v. Flathers, 57 S. D. 320,232 N. W. 51 (1930). "This malice is so odious in law, as though it be intended against one, it shall be extended towards another." 3 Co. INST. (1797) 51 .

109. People v. Weeks, 104 Cal. App. 708, 286 Pac. 514 (1930); Durham v. State, 171 S. E. 265 (Ga. 1933). Under some statutes such a homicide will be a different degree of murder than if the fatal force had reached its intended victim. See, for example, Honeycutt v. State, 42 Tex. Cr. App. 129, 132, 57 S. W. 806, 807 (1900). 
homicide into two grades depending upon the presence or absence of malice aforethought) ${ }^{110}$ says that if a servant beats a man at the command of his master, and the man dies of the beating, it is murder by both, no qualification being mentioned as to the nature or extent of the beating, either inflicted or commanded. ${ }^{111}$ This, in substance, is repeated by Coke, ${ }^{112}$ who, moreover, defines express malice aforethought in terms of an intent "to kill, wound, or beat another."113 Hale is even more specific, saying: "Malice in fact is a deliberate intention of doing any bodily harm to another, whereunto by law he is not authorized."114 An important qualification is suggested by Blackstone, who says that one may be guilty of murder if he "beats another in a cruel and unusual manner so that he dies, though he did not intend his death."11s And East speaks of an intent "to deprive another of life, or do him some great bodily harm." Perhaps such statements as those of Lambard, Coke, and Hale represent an inadvertent carry-over from an earlier time, when nearly every homicide was a capital offense, at least in legal theory, and when pardons were probaby not recommended except for those who were thought to be entirely free from fault. However this may be, it is well established at the present time that the degree of bodily violence intended is a vital matter in this regard. It may be so great as to constitute malice aforethought (in the absence of justification, excuse or mitigation), although the resulting death is not a part of the actual design; ${ }^{117}$ or it may be too slight for this purpose. ${ }^{118}$ "Every assault," the Michigan court has said, "involves bodily harm, but any doctrine which would hold every assailant as a murderer where death follows his act, would be barbarous and unreasonable."110 To designate the degree of intended bodily violence, less than death, which is sufficient to constitute malice aforethought (in the absence of justification, excuse or mitigation), the courts have made

110. The statutes were enacted in $1496,1512,1531$, and 1547. See note 60 , supra. Eirenarcha was written in 1581 . See note 73 , supra.

111. LAMIBARD, op. cit. supra note 74, at 244.

112. 3 Co. INST. (1797) 51.

113. Ibid.

114. 1 HALE P. C. (1847) 451 (italics added). In the case of correction of a servant by his master, Hale distinguishes between moderate correction and immoderate correction. But this is upon the notion that a moderate correction was authorized by law in such a case and hence not unlawful at all. Id. at 454 .

115. 4 Bz. Conar. (1897) 199.

116. 1 EAST P. C. (1806) 222.

117. State v. Calabrese; Commonwealth v. Marshall, both supra note 10 .

118. McAndrews v. People, supra note 92, at 548, 208 Pac. at 490 ; People v. Crenshaw, 298 Ill. $412,417,131$ N. E. 576, 578 (1921).

119. Wellar v. People, 30 Mich. 16, 20 (1874). 
use of such expressions as "grievous mischief,",120 "great bodily harm,"121 or "serious bodily harm.".122

Obviously no mere phrase can serve as a solvent for all cases in which this problem may be involved, but such characterizations point in the general direction and the decided cases give additional guidance. If the purpose is to cause bodily injury by means of a "deadly weapon"123 or a "dangerous instrument," or injury, assuming that the weapon or instrument is used in a dangerous manner, ${ }^{125}$ even if there is no actual design to cause death. ${ }^{126}$ This is true, for example, where the defendant shot at the deceased, ${ }^{127}$ or cut him across the neck with a razor, ${ }^{128}$ or hit him over the head with a heavy iron bar, ${ }^{129}$ or threw at him a heavy glass tumbler, ${ }^{130}$ or a rock "the size of a man's fist,"131 or choked him violently though without intending to kill. ${ }^{132}$ The old formula of finding an intent to kill because "one is presumed to intend the natural and probable consequences of his act" is sometimes encountered in such cases, ${ }^{133}$ but this should yield to a more accurate analysis. The intent to inflict great bodily injury is sufficient without an actual design to cause death. ${ }^{134}$ Acts such as indicated in the illustrations may give rise to an inference of fact that there was an actual intent to kill; but this inference may be overcome by evidence. If this

120. Ibid.

121. Commonwealth v. Marshall, supra note 107, at 519, 135 Atl. at 303.

122. Martinez v. State, 30 Tex. App. 129, 137, 16 S. W. 767, 768 (1891).

123. People v. Collins, 166 Mich. 4, 7, 131 N. W. 78, 80 (1911); Commonwealth v. Robinson, $305 \mathrm{~Pa} .302,310,157$ Atl. 689, 692 (1931); State v. Wilson, supra note 92.

124. McAndrews v. People, supre note 92; State v. Brown, 152 Iowa $427,437,132$ N. W. 862,866 (1911).

125. For example, while a sword is a deadly weapon, an intent to slap another across the back with the flat side of the blade might not involve an intent to inflict great bodily injury. On the other hand a heavy revolver might be used in a dangerous manner by using it as a club to strike another over the head, as well as by shooting with it.

126. State v. Calabrese, supra note 107.

127. Ibid.

128. Rhodes v. State, 104 Fla. 520, 140 So. 309 (1932).

129. Grey's Case, Kel. J. 64 (Eng. 1666); Commonwealth v. Dillard, 169 Atl. 138 (Pa. 1933).

130. Mayes v. People, 106 Ml. 306 (1883).

131. Killian v. State, 184 Ark. 239, 42 S. W. (2d) 12 (1931). This was an assault case in which the court said it would have been murder if the victim had died.

132. Commonwealth v. Marshall, supra note 107.

133. See, for example, McAndrews v. People, supra note 92, at 548, 208 Pac. at 488; People v. Crenshaw, supra note 118 . In these cases it was held that the particular force used was insufficient to create this "presumption" because death was not the natural and probable result.

134. State v. Calabrese, supra note 107. 
inference is overcome the accused is still guilty of murder (in the absence of justification, excuse or mitigation), but under many statutes it may be a different degree of murder than it would be if the purpose to cause death had been established. ${ }^{135}$

On the other side attention must be directed to the difference between a battery and great bodily injury. The former may be substantially more than "technical" without meeting the requirements of the latter. And in pursuing this inquiry no group of cases will be found more useful than those involving a blow with the fist. Such a blow, particulary if directed at the head or face, may be expected to cause pain, and even actual injury-such as a broken nose or jaw. Under ordinary circumstances, however, it does not measure up to the degree of violence which the courts have in mind when phrases such as "grievous bodily harm" or "great bodily injury" are used in the homicide cases. ${ }^{136}$ Where there is great disparity of strength between the assailant and his victim, by reason of the latter being very young or very old or enfeebled by disease, for example, even an attack with the bare hands may be sufficient to constitute malice aforethought. ${ }^{137}$ The same may be true if the beating is long continued, ${ }^{138}$ or if there is some dangerous advantage of position. ${ }^{130}$ And while an intent to administer an ordinary kick is not suffcient for malice aforethought, one may be guilty of murder by stamping upon a prostrate victim until death ensues. ${ }^{140}$

\section{Wanton and Wilful Disregard of Unreasonable Human Risk}

Reference to the intent to kill or to cause great bodily injury must not divert attention from the possibility of malice aforethought in the absence

135. Commonwealth v. Marshall, supra note $10 \%$.

136. McAndrews v. People, supra note 92; Commonwealth v. Fox, 73 Mass. 585, 589 (1856).

"Death or great bodily harm must be the reasonable or probable consequences of the act to constitute murder. . . . The striking of a blow with the fist on the side of the face or head is not likely to be attended with dangerous or fatal consequences, and no inference of an intent to kill is warranted from the circumstances disclosed by the proof in this case." Hence the killing was manslaughter rather than murder. People v. Crenshaw, supra note 118 , at $416,417,131$ N. E. at 577.

137. Macklin's Case, 2 Lewin C. C. 225, 226 (Eng. 1838); McAndrews v. People, supra note 92; Commonwealth v. Fox, supra note 136.

138. Macklin's Case, supra note 137.

139. If the bare hands are used to choke the victim, for example, this may be sufficient for malice aforethought. Commonwealth v. Marshall, supra note 107.

140. Murphy v. People, 9 Colo. 435, 13 Pac. 528 (1886) ; Maudling v. Commonwealth, 172 Ky. 370, 189 S. W. 251 (1916). 
of either. The approach to this side of the problem has been well expressed as follows: "As far as wickedness goes it is difficult to suggest any distinction worth taking between an intention to inflict bodily injury, and reckless indifference whether it is inflicted or not."141 One may be guilty of murder for killing a person as a result of shooting "regardless of consequences" into a crowd,,$^{142}$ or into a room, ${ }^{143}$ or a house ${ }^{144}$ where persons are known to be, or into a train ${ }^{145}$ or an automobile $\mathrm{e}^{140}$ in which persons are known to be riding. "If he did this," said one court in a case of this nature, "not with the design of killing any one, but for his diversion merely, he is guilty of murder."147 In a well-known case a man threw a heavy glass tumbler in the direction of his wife. The glass hit a lamp she was carrying and caused the oil therein to take fire and burn her, causing her death. This was held to be murder whether he intended the tumbler to hit his wife, or to hit some other person, or whether, without any specific intent, he threw the glass with a general malicious recklessness, disregarding any and all consequences. ${ }^{148}$

Not only may malice aforethought be present when there is no actual design to kill or injure; it may even co-exist with a definite wish that such harm may be avoided, if an act is wilfully done with the knowledge that it may probably cause death or great bodily injury. ${ }^{149}$ This, however, must not be confused with criminal negligence. One who fails to exercise due care under the circumstances, is negligent. But to convict of crime on the ground of homicide resulting from negligence "there must be shown more gross and culpable negligence than is sufficient to render a defendant liable in a civil suit."150 If such criminal negligence is shown it will support a conviction of manslaughter. ${ }^{151}$ Hence for an unintentional homicide to be murder it must involve a greater degree of culp-

141. 3 STEPHEN, op. cit. supra note 11 , at 56 .

142. Durham v. State, supra note 109; State v. Saunders, 108 W. Va. 148, 150 S. E. 519 (1929).

143. State v. Capps, 134 N. C. 622,46 S. E. 730 (1904).

144. People v. Jernatowski, supra note 82.

145. Banks v. State, 85 Tex. Cr. App. 165, 211 S. W. 217 (1919).

146. Davis v. State, 106 Tex. Cr. App. 300, 292 S. W. 220 (1927).

147. Brown v. Commonwealth, 13 Ky. L. Rep. 372, 373, 17 S. W. 220, 221 (1891).

148. Mayes v. People, supra note 130.

149. State v. Capps, sutpra note 143.

150. State v. Blaine, 104 N. J. I. $325,328,137$ Atl. 829,831 (1928). See also Fitzgerald v. State, 112 Ala. 34, 20 So. 966 (1895); State v. Davis, 128 S. C. 265, 122 S. E. 770 (1924). Statutory negligent homicide occasionally omits this requirement. People v. Campbell, 237 Mich. 424, 212 N. W. 97 (1927).

151. Herrington v. State, 31 Ga. App. 167, 120 S. E. 554 (1923); Commonwealth v. Mayberry, 290 Pa. 195, 138 Atl. 686 (1927). 
ability than is implied in the term "criminal negligence." To express this notion the courts have resorted to such forms of expression as, "an act dangerous to others . . . done so recklessly or wantonly as to evince depravity of mind and a disregard of human life"; and conduct as indicate a reckless disregard of human life"; $e^{153}$ "an intent to do any unlawful act which may probably result in depriving the party of life"; tends to destroy the life of a human being."155 And one of the leaders of the law has spoken of an act done with "knowledge of such circumstances that according to common experience there is a plain and strong likelihood that death will follow the contemplated act."156

So far attention has been directed to the intent to kill, the intent to inflict great bodily injury, and the wilful doing of an act under such circumstances that there is obviously a plain and strong likelihood that death or great bodily injury may result. If this covered the entire field of our investigation it would be quite proper to speak of malice aforethought in terms of a "man-endangering-state-of-mind." A "man-killingstate-of-mind" would be too narrow and would require fiction to be substituted for a frank recognition of the necessary psychical fact. A "manhurting-state-of-mind" would cover too much in some respects, by including the intent to inflict a hurt amounting to less than great bodily injury, while it would be too narrow in another direction. The expression "man-endangering-state-of-mind," however, seems to be free from these objections even if the exact meaning assigned to it is somewhat arbitrary. But may it properly be applied to homicides committed while perpetrating or attempting a felony, or while resisting a lawful arrest, or a lawful attempt to suppress a riot or an affray?

\section{VI}

\section{Homicide Resulting from Felony}

The first of these has been the subject of much judicial consideration. The robber who kills the person he is attempting to rob, is guilty of murder whether he intended any personal harm or not. ${ }^{157}$ If he holds up

152. State v. Capps, supra note 143 , at 629,46 S. E. at 732 .

153. State v. Collins, 5 Penn. 263, 269-70, 62 Atl. 224, 226 (Del. 1903).

154. Shorter v. State, 147 Tenn. 355, 358, 247 S. W. 985, 986 (1922).

155. Ashford v. State, 144 Ga. 832, 88 S. E. 205 (1916).

156. Per Holmes, C. J., in Commonwealth v. Chance, sutpra note 98 , at $252,54 \mathrm{~N}$. E. at 554 .

157. McCutcheon v. State, supra note 21 , at 257,155 N. E. at 548; Commonwealth v. Madeiros, supra note 82; State v. Bell, 205 N. C. 225, 171 S. E. 50 (1933); Commonwealth v. Epps, 193 Pa. 512, 518, 44 Atl. 570, 571 (1899); Commonwealth v. Dillard, supra note 129 . 
the victim at the point of a gun and the weapon goes off, causing death, it makes no difference that the discharge was quite accidental. ${ }^{10 s}$ It is no element of mitigation that he was "shaking and nervous and pulled the trigger" unintentionally, ${ }^{150}$ nor that the weapon was unexpectedly seized and went off by accident during a struggle for its possession. ${ }^{100}$ Train robbers who forced a brakeman to go with them to the express car were held guilty of his murder, although the death resulted from a shot fired by a passenger in the defense of the car, since they had feloniously exposed him to this risk. ${ }^{161}$ One who commits arson may be found guilty of the murder of an inhabitant of the building who lost his life in the fire even though personal injury was neither intended nor contemplated. ${ }^{162}$ Even if there was no person in the building when the fire was feloniously started, the incendiary may be convicted of murder if a fireman is killed in the effort to extinguish the blaze. ${ }^{163}$ A rapist who causes the death of his victim by this felonious force is guilty of murder. ${ }^{104}$ This is true even if the death is quite unintentional, and whether it resulted from violence used by him to perpetrate the act, ${ }^{165}$ or from a disease communicated by him during the intercourse. ${ }^{166}$ A burglar, moreover, is guilty of murder if homicide results from the perpetration of this offense. ${ }^{167}$ In fact it is a common statement that homicide committed while perpetrating or attempting a felony is murder. ${ }^{108}$

A glance at the history of this subject will disclose that here also there

158. Commonwealth v. McManus, supra note 21.

159. McCutcheon v. State, supra note 21.

160. Commonwealth v. Lessner, $274 \mathrm{~Pa}$. 108, 118 Atl. 24 (1922); State v. Best, supra note 21.

161. Keaton v. State, 41 Tex. Cr. App. 621, 57 S. W. 1125 (1900).

162. Reddick v. Commonwealth, 17 Ky. L. Rep. 1020, 33 S. W. 416 (1895); State v.

Meadoẃs, 330 Mo. 1020, 51 S. W. (2d) 1033 (1932).

163. State v. Glover, supra note 82 .

164. Commonwealth v. Hanlon, 8 Phila. 401 (Pa. 1870); State v. Whitfield, 129 Wash 134, 224 Pac. 559 (1924).

165. Buel v. People, 78 N. Y. 492 (1879).

166. Regina v. Greenwood, 7 Cox C. C. 404 (1857). As this was statutory rape the jury was reluctant to bring in a verdict of guilty of murder, and the court permitted them to find the defendant guilty of manslaughter. But the instruction authorized the other verdict.

167. People v. Green, 217 Cal. 176, 17 P. (2d) 730 (1932).

168. Perhaps the most common citation is a dictum in Rex v. Plummer, Kel, 109, 117 (1701): "So if two men have a design to steal a hen, and one shoots at the hen for that purpose, and a man be killed, it is murder in both, because the design was felonious." See also Regina v. Horsey, 3 Frost. \& F. 287, 288-9 (1862) ; State v. Cross, 72 Conn. 722, 729, 46 Atl. 148, 151 (1900); State v. Leeper, 70 Iowa 748, 30 N. W. 501 (1886); Smith v. State, 33 Me. 48, 55 (1851); State v. Hopkirk, 84 Mo. 278, 287 (1884); State v. Cooper, 13 N. J. L. 361, 370 (1833); Dolan v. People, 64 N. Y. 485 (1876). 
has been a decided shift in the legal view during the centuries. "If the act be unlawful," said Coke, "it is murder."169 Hale was unwilling to repeat such a sweeping assertion. He gives illustrations of unlawful acts resulting in death which he says are murder, ${ }^{170}$ and others which he classifies as manslaughter. ${ }^{171}$ This limitation is given more definite form by Foster, who says that an accidental homicide resulting from an unlawful act (with the qualification-"if it be malum in se") is murder if the crime be of the grade of felony, but that otherwise it is manslaughter. ${ }^{172}$ Foster's view was accepted by Blackstone ${ }^{173}$ and East, ${ }^{174}$ but Judge Stephen was very positive that this was still too broad. "To take another very old illustration," said he in a famous case, ${ }^{175}$ "it was said that if a man shot at a fowl with intent to steal it, and accidentally killed a man, he was to be accounted guilty of murder, because the act was done in the commission of a felony. I very much doubt, however, whether that is really the law, or whether the court for the Consideration of Crown Cases Reserved would hold it to be so." In fact he seemed inclined to require for murder, in such a case, the same degree of wanton and wilful disregard for human life which would constitute malice aforethought if no felony were being attempted. ${ }^{176}$

The present law of England seems to fall midway between the views of Foster and Stephen. Not every death resulting from an act done in the commission of a felony is murder, but such a homicide may constitute this crime without the same degree of human risk being involved as would otherwise be requisite. It is not necessary to show the wilful doing of an act under such circumstances that there is obviously a plain and strong likelihood that death or great bodily injury may result. On the other hand the element of human risk cannot be excluded without at the same time excluding the possibility of murder. "If a man by the

169. 3 Co. INST. (1797) 56.

170. 1 HALE P. C. (1847) 465.

171. Id. at 475 .

172. Foster C. C. (1791) 258.

173. "And if one intends to do another felony, and undesignedly kills a man, this is also murder." 4 BL. Cosnr. (1897) 200-1.

174. 1 EAST P. C. (1806) 255.

175. Regina v. Serné, 16 Cox C. C. $311,312-3$ (1887). Holdsworth doubts whether the rule as stated by Foster would now be followed without some limitation. 8 HordsworTH, op. cit. supra note 26 , at 436 .

176. "I think that, instead of saying that any act done with intent to commit a felony and which causes death amounts to murder, it would be reasonable to say that any act known to be dangerous to life, and likely in itself to cause death done for the purpose of committing a felony, which caused death, should be murder." Regina v. Serné, supra note 175 , at 313 . 
perpetration of a felonious act brings about the death of a fellow creature he is guilty of murder, unless when he committed the felonious act the chance of death resulting therefrom was so remote that no reasonable man would have taken it into his consideration. In that case he is not guilty of murder, but only of manslaughter."177

Such a position has much to commend it. It places upon the man who is committing or attempting a felony the hazard of guilt of murder if he creates any substantial human risk which actually results in the loss of life; and it does this without including within this offense those homicides which occur so unexpectedly that no reasonable man would have considered that any risk of this nature was involved. Certain felonies have so frequently been attended with death or great bodily harm, which was not intended or contemplated by the particular wrongdoer, that they must be classified as "dangerous." Common experience points to the presence of a substantial human risk from the mere perpetration of such wrongful acts. The typical examples are arson, burglary, rape, and robbery. The intent to avoid all personal harm, formed in the mind of the transgressor at the time he embarks upon such felonies, is no reasonable safeguard that death will not result before he is finished. If we add to this list the crime of larceny, and those offenses which directly contemplate death or great bodily injury, we have completed the list of commonlaw felonies. ${ }^{179}$ In other words, with the single exception of larceny, the common-law felonies were either directed toward death or great bodily injury, or involved a substantial risk of this nature. And while an attempted larceny happens to be the "very old illustration" used by Coke ${ }^{180}$ (who regarded homicide resulting from any unlawful act as murder) ${ }^{181}$

177. Regina v. Whitmarsh, 62 Just. P. 711 (1898). The quotation is from the syllabus. To the same general effect see Rex v. Lumley, 22 Cox C. C. 635 (1911).

178. It has not been uncommon to provide, by statute, that murder committed by perpetrating or attempting such felonies shall be of the first degree. See, for example, ArIz. Code (Struckmeyer, 1928) \$ 4584; CaL. PeN. Code (Deering, 1931) § 189; Conn. Gen. Stat. (1923) § 21-401; Fla. Con.P. Laws (1927) § 7137; Iowa Code (1931) § 12911; Mich. Cosm. Laws (1929) \& 16708; Ore. CODE ANN. (1930) § 14-201. Many considerations may have been involved in such legislative action, but the peculiar element of human risk in such offenses was probably not overlooked. This is emphasized by additions sometimes made to this list, such as mayhem, which is common, or "injury to any person or property by means of any explosive compound" (Conn.).

179. Pollock and Maitland add false imprisonment. 2 Porrock AND MartcaNd, op. cit. supra note 24 , at 468,487 . But see 3 BL. Conns. (1897) 127; 4 id. 218; 1 EAST P. C. (1806) c. 9 .

180. ". . . if A, meaning to steale a deere in the park of B, shooteth at the deer, and by the glance of the arrow killeth a boy that is hidden in a bush: this is murder . . . although $A$ had no intent to hurt the boy, nor knew not of him." 3 Co. INst. (1797) 56.

181. See note 169 , supra. 
and also the subject of a much cited dictum, ${ }^{182}$ a study of the cases which repeat the formula that homicide committed while perpetrating or attempting a felony is murder, will disclose that the other felony actually involved is one which may properly be classified as "dangerous," such as robbery, ${ }^{183}$ rape, ${ }^{184}$ burglary, ${ }^{185}$ arson, ${ }^{186}$ malicious burning, ${ }^{187}$ or criminal abortion. ${ }^{188}$

To test whether the statement, in its unlimited form, actually represents the law of this country, it is necessary to consider felonies of a nondangerous nature. Furthermore, an additional caution must be added. One who is perpetrating a felony which seems not of itself to involve any element of human risk, may resort to a dangerous method of committing it, or may make use of dangerous force to deter others from interfering. If the dangerous force thus used results in death, the crime is murder just as much as if the danger was inherent in the very nature of the felony itself. For obvious reasons a felony which does not of itself involve any substantial element of human risk, and which is not accompanied in the particular instance by the use of dangerous force, will very rarely result in the death of a human being. Because of this very few cases squarely raise the question. The matter, however, has not escaped attention in this country. The Kentucky court has given a striking illustration in a very famous case. ${ }^{189}$ "Under our statute," said the court, "the removal of a cornerstone is punishable by a short term in the penitentiary, and is therefore a felony. If, in attempting this offense, death were to result to one conspirator by his fellow accidentally dropping the stone upon him, no Christian court would hesitate to apply this limitation." The "limitation" mentioned is that the homicide would be manslaughter rather than murder notwithstanding it resulted from the commission of a felony. An intimation to this effect, though not so directly stated, was mentioned by the New Jersey court a hundred years ago. ${ }^{100}$

182. Rex v. Plummer, supra note 168. The actual case involved armed resistance to arrest and the special verdict indicated that the discharge of the weapon was not by accident.

183. Commonwealth v. Madeiros, supra note 82; State v. Hopkirk, supra note 168; People v. Koerber, 244 N. Y. $147,152,155$ N. E. 79, 82 (1926); McDonald v. State, 15 P. (2d) 1094 (Okla. 1932).

184. State v. Cross, sutpra note 168.

185. Dolan v. People, supra note 168 ; People v. Greenwall, 115 N. Y. 520, 522-3, 22

N. E. 180 (1889).

186. State v. Glover, supra note 82; State v. Cooper, sulpra note 168.

187. Regina v. Horsey, supra note 168.

188. State v. Leeper; Smith v. State, both supra note 168.

189. Powers v. Commonwealth, 110 Ky. 386, 416, 61 S. W. 935,63 S. W. 776 (1901).

190. In stating the rule that death resulting from a felony is murder, the court added 
The leading American decision on this point is one handed down in Michigan a few years ago. ${ }^{101}$ The defendant sold liquor, under circumstances amounting to a felony, to a purchaser who became drunk and died from exposure. The court refused to hold that the mere fact of this accidental death resulting from this felony was sufficient to constitute the offense of murder. "Notwithstanding the fact that the statute has declared it to be a felony," reads the opinion, "it is an act not in itself directly and naturally dangerous to life."

The formula that homicide committed while perpetrating or attempting a felony is murder must also be challenged because it speaks in terms of coincidence, whereas the requirement is causation. ${ }^{102}$ The word "while" is inaccurate and misleading in this connection. Of less importance, though not to be entirely overlooked, is a purely technical point. It would be futile to recognize the sudden heat of passion, engendered by great provocation, as sufficiently mitigating to reduce a voluntary homicide to manslaughter, if in the next breath it was added that manslaughter is a dangerous felony and hence any homicide resulting therefrom must be murder. It is not necessary to mention other types of this offense. The distinction between murder and manslaughter, felonies both, makes it necessary to qualify any rule as to the nature of homicide resulting from felonies by limiting it to felonies other than felonious homicide itself. This has usually been taken for granted, but sometimes it has been forced upon the attention of the courts in the interpretation of statutes. In such cases the courts have held it to be essential in order

this significant qualification,--"especially if death were a probable consequence of the act." State v. Cooper, supra note 168 . This qualification probably requires a greater degree of human risk than would be insisted upon for malice aforethought in a felony case, but it indicates that the court, even at that time, was not entirely satisfied with the statement in unlimited form.

191. People v. Pavlic, 227 Mich. 562, 119 N. W. 373 (1924).

192. For example, a Texas statute declares driving while intoxicated to be a felony. And this would seem to be clearly a dangerous felony. But it was held that if one, driving while intoxicated, suddenly has a flat tire which swerves the car into a ditch where another is hit and killed, he is not by reason of this fact alone guilty of murder. Burton v. State, 55 S. W. (2d) 813 (Tex. Cr. App. 1932). As it is sometimes said, it is necessary to show that "death ensued in consequence of the felony," Buel v. People, 7S N. Y. 492, 497 (1879); or that it was "consequent to the felony." Pliemling v. State, 46 Wis. 516, 521, 1 N. W. 278, 281 (1879). See also a manslaughter case in which it was held necessary to establish a causal connection between the unlawful act and the death. Jackson v. State, 101 Ohio St. 152, 127 N. E. 870 (1920). It was said in another manslaughter case: "And where an allegation that the defendant did an unlawful act is relied on, as in the first count, the mere averment that 'while' this unlawful act was being done, the defendant killed another by accident or mischance does not supply the place of averments of facts showing that the alleged unlawful act was a proximate cause of the homicide." Kimmel v. State, 198 Ind. 444, 455, 154 N. E. 16, 20 (1926). 
to bring the case within this rule, that the slayer was engaged in some other felony, so distinct "as not to be an ingredient of the homicide" itself. $^{103}$

To stress these qualifications it should be stated that homicide is murder (if no statute in the particular jurisdiction requires a different answer $)^{104}$ provided the death ensues in consequence of some other felony which involves a substantial element of human risk, or is caused by a dangerous act committed in furtherance of such felonious design. To this may be added the explanation, previously suggested, that the danger here referred to may fall considerably short of a plain and strong likelihood that death or great bodily injury will result, but must not be so remote that no reasonable man would have taken it into consideration.

\section{VII}

\section{Resistance to Lawful Arrest, and to a Lawful Attempt to Suppress a Riot}

Homicide resulting from resistance to a lawful arrest seems to require a similar explanation. At a time when malice aforethought was understood to include a substantial element of time, an intentional killing by one who was resisting a lawful arrest, with full knowledge of the circumstances, was held to satisfy this requirement: "the law will adjudge it to be murder, and that the murderer had malice prepense, because he set himself against the justice of the realm."195 The apparent rationalization, that such a one had thought the matter over in advance and determined rather to kill than to be taken into custody, ${ }^{196}$ may be fictitious rather

193. State v. Fisher, 120 Kan. 226, 230, 243 Pac. 291, 293 (1926); People v. Hüter, 184 N. Y. $237,244,77$ N. E. 6,8 (1906).

194. If the statute changes the rule of the common law by adding the word "purposely" in the section dealing with murder, an unintentional killing will not qualify even if it results from a dangerous felony. See O\#ت CoDE (1930) § 12403; Robbins v. State, 8 Ohio St. 131 (1857). Compare $\S 12401$ in which the word "purposely" does not appear. On the other hand, a statute providing that "homicide is murder . . . when perpetrated without any design to effect death by a person engaged in the commission of any felony" seems to cover every case in which there was a legally recognizable causal connection between the felonious act and the death, however remote the element of human risk may seem to have been. See OrIa. Stat. (1931) § 2216. See also Wis. Stat. (1931) § 340.09; N. Y. PEN. LAW (1929) § 1044. And see State v. Welch, 25 P. (2d) 211 (N. M. 1933).

195. Yong's Case, 4 Co. Rep. 40a (1587) (italics added).

196. The old books do not spell this out for us in detail, but Lambard leaves no doubt that he was thinking along this general line. This is one of the instances in which he says the law judges a killing "to have proceeded of former malice, meditated within his owne mind, howsoever it be kept secret from the sight of other men." LARIBARD, op. cit. supra note 74 , at 242 . And in another instance, that of the thief who killed another whom he intended to rob, he amplifies by saying that the law "implyeth a former malicious disposition in him rather to kill the man than not to have his money from him." Id. at 244. 
than a reasonable inference of fact. But the starting point is a pronouncement on the subject which was not dealing with accidental and unexpected homicides. ${ }^{197}$ Lambard limits his statement to that of a man who "hath drawne his weapon, and killed."198 Coke, who regarded homicide resulting from any unlawful act as murder, ${ }^{199}$ quite logically placed in the same category the killing of one who was making a lawful arrest. ${ }^{200}$ And his generalization has been frequently repeated. ${ }^{201}$ However, a study of the cases in which this statement appears will ordinarily disclose that the killing resulted from shooting ${ }^{202}$ or from the use of some other dangerous force, such as stabbing with a knife ${ }^{203}$ or striking with a heavy club. ${ }^{204}$ It is sometimes said that no particular malice is required to establish murder in such a case ${ }^{205}$ but it would be more accurate to

Yong's Case, supra note 195, is also interesting in this respect. This case held that one who killed to avoid arrest was guilty of murder although he "knew not the party that was killed." This statement seems meaningless in a murder case until we recall the normal requirement of the time, that the malicious scheme must have been thought of well in advance of the fatal act. The explanation seems to be that although he had not designed harm against this very person, he had malice prepense because he had determined to use fatal force if necessary to avoid arrest. In another case, in which no resistance to arrest was involved, the jury was instructed as follows: "Now it hath not been made [to] appear by any of the evidence that you have heard, that there was any premeditated malice between them, for they were never in company before, and knew not each other; so that there could be no manner of malice from him in particular. The next step, Gentlemen, is, here is nothing that can impute a general malice upon Mr. Walters." Walter's Case, 12 St. Tr. 113, 121-2 (Eng. 1688).

197. The statutes which resulted in the division of felonious homicide into murder and manslaughter were enacted in $1496,1512,1531$ and 1547 . See note 60 , supra. Writers before this period would not be concerned with this distinction, and Lambard seems to have made the first pronouncement on the subject of homicide resulting from resisting a lawful arrest, insofar as its bearing upon malice aforethought is concerned.

198. LAMBaRD, op. cit. supra note 74, at 243.

199. 3 Co. Inst. (1797) 56.

200. Id. at 52 .

201. See, e.g., 1 Hale P. C. (1847) 457; Foster C. C. (1791) 270; 1 EAST P. C. (1806) 302. See also the cases in notes 202-204.

202. See, for example, Brooks v. State, 114 Ga. 6, 39 S. E. 877 (1901); Williford v. State, 121 Ga. 173, 48 S. E. 962 (1904); Kennedy v. State, 107 -Ind. 144, 6 N. E. 305 (1886); State v. Mowry, 37 Kan. 369, 15 Pac. 282 (1887) ; Cornett v. Commonwealth, 198 Ky, 236, 248 S. W. 540 (1923); Sexson v. Commonwealth, 239 Ky. 177, 179, 39 S. W. (2d) 229, 230 (1931); State v. Green, 66 Mo. 631, 646 (1877); State v. Albright, 144 Mo. 638, 46 S. W. 620 (1898) ; Bullock v. State, 65 N. J. L. 557, 47 Atl. 62 (1900); State v. Genese, 102 N. J. L. 134, 130 Atl. 642 (1925); Love v. State, 15 Okla. Cr. App. 429, 177 Pac. 387 (1919); Wilson v. State, 79 Tenn. 310 (1883); State v. Morgan, 22 Utah 162, 61 Pac. 527 (1900).

203. State v. Zeibart, 40 Iowa 169 (1874).

204. Glaze v. State, 156 Ga. 807,120 S. E. 530 (1923).

205. Donehy \& Prather v. Commonwealth, $170 \mathrm{Ky} .474,186$ S. W. 161 (1916). The killing was by shooting. 
say that one who is resisting a lawful arrest (that is, an arrest which is authorized by law and is being made in a proper manner) is acting without justification, excuse ${ }^{206}$ or provocation, ${ }^{207}$ and hence that his intent to make use of deadly force is malice aforethought.

The act of resisting arrest is seldom made under circumstances which seem to involve no element of human risk; and in the few instances in which this does happen, fatal consequences are quite improbable. Therefore it would not be surprising if this were a matter which had not been forced upon the attention of the courts. In truth, however, it has received judicial attention both in England and in this country. In Regina $v$. Porter, ${ }^{208}$ the defendant refused to enter the vehicle which was to take him to jail. The officer making the arrest called assistance for the purpose of forcing the defendant to enter, and one of the persons aiding the officer was killed by a kick from the defendant. The court instructed the jury that if the defendant intentionally kicked the deceased in resisting a lawful attempt to take the defendant to jail, the homicide was murder; but that if his foot happened by accident to strike the other while the defendant was struggling to avoid being put into the carriage, the crime was manslaughter only. And the jury found him guilty of the lesser crime. The same problem was presented in different form in State v. Weisengoff. ${ }^{209}$ An officer stepped upon the running board of defendant's car for the purpose of making an arrest which was entirely lawful under the circumstances. The defendant was very near the state line and attempted to drive across a bridge into the neighboring jurisdiction. In this attempt the car struck the bridge and the officer was killed. It is quite possible the act may have been sufficiently dangerous to support a conviction of murder; but the jury was not permitted to inquire into this aspect of the matter. One who caused death by knowingly resisting a lawful arrest, according to the instruction to the jury, was guilty of murder without reference to malice. This was held to be such prejudicial error as to call for a new trial.

The very nature of a riot or an affray is such as to make it highly

206. If there is legal authorization for the arrest and it is being made in a proper manner the person to be arrested has no right to resist. Floyd v. State, 82 Ala. 16, 2 So. 683 (1886). This is true even if he is innocent of the charge for which he is to be arrested. rbid. As the one being arrested is entirely in the wrong if he resists, he cannot invoke the principle of self-defense. White v. State, 70 Miss. 253, 11 So. 632 (1892).

207. A lawful arrest "can, of itself, be no provocation in law, since every person is bound to submit to the regular course of justice." State v. Spaulding, 34 Minn. 361, 363, 25 N. W. 793 (1885).

208. 12 Cox C. C. 444 (1873).

209. 85 W. Va. 271,101 S. E. 450 (1919). 
unlikely that an attempt to suppress either will be resisted in a manner which involves no substantial element of human risk. If this should happen, however, and death should unexpectedly result from an act which seemed so harmless that no reasonable man would have taken into consideration the possibility of fatal consequences, the courts will no doubt deal with it as in similar situations in the arrest cases, and hold it manslaughter rather than murder. Hence it seems proper to say of homicides resulting from resistance to a lawful arrest or from resistance to a lawful attempt to suppress a riot or an affray - as was said of homicides resulting from felony-that malice aforethought may be found without the same degree of human risk having been involved as would otherwise be needed ${ }^{210}$ but that the element of human risk cannot be excluded entirely without excluding murder. It would therefore seem not improper to speak of malice aforethought, in all cases, in terms of a "man-endangering-state-of-mind," with the explanation that this means an intent to kill, or an intent to inflict great bodily injury, or an intent to do an act under such circumstances that there is obviously a plain and strong likelihood that death or great bodily harm may result, or-in the case of one who is committing or attempting a felony, or resisting a lawful attempt to make an arrest or to suppress a riot or an affray-an intent to do any act involving a substantial element of human risk.

\section{VIII}

\section{Conclusion}

The phrase "man-endangering-state-of-mind," if accepted for this purpose and with this explanation, tells only part of the story, for such a state of mind will not constitute malice aforethought if there are circumstances of justification, excuse or mitigation. ${ }^{211}$ The classic statement in

210. For example, although an ordinary kick does not threaten such great bodily injury as to amount to malice aforethought, the court, in Regina v. Porter, supra note 20s, instructed the jury that if defendant intentionally kicked the deceased in his effort to resist being taken to jail, he was guilty of murder.

211. It is more common to use the words "justification, excuse or provocation" in this connection; but if a third word is needed "provocation" is inadequate because there may be circumstances sufficiently mitigating to reduce a voluntary homicide to manslaughter, although no provocation is involved. For example, suppose the defendant thought he was in imminent danger of death and that he must kill to save his life, and he did kill for this reason. Suppose, also, there was no actual danger to him at the moment, and the facts fall a little short of reasonable ground for a belief in such danger. In such a case the homicide is not entirely excused, but the guilt is manslaughter rather than murder although there was no act of provocation. Bliss v. State, 117 Wis. 596, 94 N. W. 325 (1903). Also, a killing to prevent crime may fall short of justification or excuse and still 
this regard is that "we may take it for a general rule that all homicide is malicious, and of course amounts to murder, unless where justified by the command or permission of the law, excused on account of accident or self-preservation, or alleviated into manslaughter by being either the involuntary consequence of some act not strictly lawful, or (if voluntary) occasioned by some sudden and sufficiently violent provocation."212 The development of the law since Blackstone's time leaves his amplifications somewhat inadequate, ${ }^{213}$ but the basic outline has been firmly established, ${ }^{214}$ and represents the legal view in our day ${ }^{215}$ as truly as it did in his. "Malice, as an ingredient of murder," it is sometimes said, "may be defined, in legal phrase, as the killing of a human being, without legal justification, excuse or extenuation."216

It is the course of caution to call attention to the fact that malice aforethought is a matter of mind, however convenient it may be to speak in terms of the absence of circumstances of justification, excuse or mitigation. It is a psychical fact just as homicide is a physical fact. It is the particular kind of mens rea or mind at fault which is required for the more serious of the two types of felonious homicide. Perhaps it would

be manslaughter rather than murder. Williams v. State, 127 Miss. 851, 90 So. 705 (1922). Hence it is better to speak in terms of mitigation, even if the mitigating factor will usually be the sudden heat of passion engendered by great provocation. The question may arise as to whether the words "justification or excuse" will not cover the entire situation. A killing in a sudden transport of passion engendered by adequate provocation is really a partial excuse for the act. Regina v. Chapman, 12 Cox C. C. 4 (1871). In such a case "the law does not wholly excuse the offense; but the law, in its charity for the imperfections and weakness of human nature, reduces it from murder to manslaughter." Addington v. United States, 165 U. S. 184, 186 (1897). See also another case in which malice was spoken of as an intent to kill "where the law would neither justify nor in any degree excuse the intention." Jones v. State, $29 \mathrm{Ga}$. 594, 607 (1860). Another court has said: "Anger, a short madness, when provoked by a reasonable cause, excuses from the punishment of murder" but not of manslaughter. Commonwealth v. Bell, Addison 156, 160 (Pa. 1793). The convenience, however, of reserving the word "excuse" for cases in which the defendant is entitled to an acquittal, justifies the addition of the word "mitigation" for those circumstances which do not establish innocence in, but are sufficient to diminish to manslaughter, a homicide that would otherwise be murder.

212. 4 Br. Conrar. (1897) 201.

213. See, for example, note 211, supra.

214. United States v. Bevans, Fed. Cas. No. 14,589 (1816); Hadley v. State, 55 Ala. 31, 38 (1876); Commonwealth v. Drum, 58 Pa. 9, 18 (1868); Jordan v. State, 10 Tex. 479, 493 (1853); McCoy v. State, 25 Tex. 33, 39 (1860); Stevens v. State, 42 Tex. Cr. App. $154,173,59$ S. W. $545(1900)$.

215. Stepp v. State, 170 Ark. 1061, 1067, 282 S. W. 684, 686 (1926); Commonwealth v. Bedrosian, 247 Mass. 573, 576, 142 N. E. 778, 779 (1924); State v. Williams, 185 N. C. $643,666,116$ S. E. 570 (1923); State v. Galvano, supra note 105 . State v. Cassim, supra note 91 .

216. Cribbs v. State, 86 Ala. 613, 616, 6 So. 109, 110 (1888). 
be more accurate to speak of it as a label which is placed upon a group of states of mind, any one of which is sufficient for murder. A manendangering-state-of-mind is not malice aforethought if there are circumstances of justification, excuse or mitigation; but such a state of mind in the presence of these circumstances is a different psychical fact than it would be if they were wanting. An intent to kill, to give a very limited illustration, may be the same intent, in a certain sense, whether it is for self-preservation, or is formed in a sudden rage engendered by great provocation, or is part of a well-laid plan for financial gain; but the psychical fact in its totality is not the same in any two of these. Furthermore, the appraisal or evaluation of appearances is also a psychical fact. Hence an intent to kill for the purpose of self-defense under circumstances in which there is reasonable ground for believing this drastic step to be necessary, is psychically different from an intent to kill in self-defense when there is nothing to warrant such a belief. In fact no inquiry into justification, excuse or mitigation in a homicide case can be dissociated from the mental element involved in criminal guilt. Perhaps the most extreme test of this point will be found in the act of carrying out a lawful sentence of death. If a sheriff is carrying out such a sentence what difference does it make what his state of mind may be? The fallacy involved in this question lies in the fact that the mental element-the mind without fault-has been satisfied by the assumption that he is "carrying out" a lawful sentence of death. If a sheriff who had no knowledge of any sentence of death having been pronounced, should take the life of his prisoner for some unlawful purpose of his own, it would be no answer to a murder charge that there existed, unknown to him, a mandate for him to execute that man on that very day. ${ }^{217}$ The extreme unlikelihood of the officer's being unaware of the existence of the sentence does not affect the legal view of such a situation. The knowledge that he is carrying out the sentence of the court makes this altogether different as a psychical fact than if he acted in ignorance of this matter.

What has been said suggests the following definition: Malice aforethought is an unjustifiable, inexcusable and unmitigated man-endangering-

217. Compare People v. Burt, 51 Mich. 199, 16 N. W. 378 (1883), in which the killing of an actual felon under circumstances which would have justified the homicide had the facts been known, was held not to constitute a justification in favor of one who did not know or have any reason to believe that the person was a felon. Cf. also: "If he vary from the judgment, as where the judgment is to be hanged, if he behead the party it is held murder. It must be done by the proper officer, viz. the sheriff or his substitute, if another doth it of his own head, it is held murder." 1 HaLe P. C. (1847) 501. See also 3 Co. Inst. (1797) 52; 4 Br. Conn. (1897) 179. 
state-of-mind. Such a statement will not in any way simplify the law of homicide, because the final phrase must have assigned to it a meaning which will need to be explained in as much detail as would be required if it were omitted. It has, however, the virtue of placing the emphasis where it belongs. It speaks of malice aforethought in terms of the state of mind of the slayer, and it does so frankly without the resort to fiction. It postulates the absence of justification, excuse and sufficient mitigation to diminish to manslaughter what would otherwise be murder, and requires either (1) an intent to kill, or (2) an intent to inflict great bodily injury, or (3) the wanton and wilful disregard of an unreasonable human risk-the wilful doing of an act under such circumstances that there is obviously a plain and strong likelihood that death or great bodily injury may result, or (4) if the person is engaged at the time in perpetrating or attempting a felony, or in resisting a lawful attempt to make an arrest or to suppress a riot or an affray, it includes the wilful doing of any act which involves a substantial element of human risk ${ }^{218}$ - with the additional explanation that the common experience of men shows such a risk to be inherent in certain felonies such as arson, burglary, rape and robbery. 219

218. The cases of criminal abortion are illuminating. At a time when surgery was in a crude stage of its development and when the character and properties of powerful drugs were little understood, the attempt to produce a miscarriage was an act which was very dangerous to human life. During that period of history an unlawful attempt to produce a miscarriage which resulted in the death of the woman was sufficient for murder because of the plain and strong likelihood that death or great bodily injury might result. 1 HaLE P. C. (1847) 429-30; 4 Br. Cosar. (1897) 201; State v. Moore, 25 Iowa 128, 136-7 (1868). The danger from such an operation has now been minimized to such an extent by the advancement of medical science that the law, at the present time, if not affected by statute, is that homicide resulting from an unlawful operation of this nature is either murder or manslaughter-murder if the act was performed in such a manner as likely to result in death or great bodily injury, and manslaughter if death happened to result by accident from means which did not render death or great bodily injury probable. Worthington $v$. State, 92 Md. 222, 237-8, 48 AtI. 355, 356-7 (1901) ; Peoples v. Commonwealth, 87 Ky. 487, 9 S. W. 509 (1888). There is still a substantial element of human risk, however, and if the criminal abortion has itself been made a felony by statute, the resulting death of the woman is murder no matter what care was used. State v. Fleetwood, 6 Penn. 153, 63 Atl. 772 (Del. 1906) ; State v. Alcorn, 7 Idaho 599, 64 Pac. 1014 (1901) ; State v. Smith, 32 Me. 369 (1851) ; State v. Belyea, 9 N. D. 353,83 N. W. 1 (1900). If the illegal operation is only a misdemeanor, the homicide is manslaughter if the act was not performed in a dangerous manner. State v. McNab, 20 N. H. 160 (1849). By legislative enactment such homicide is sometimes declared to be murder. Johnson v. People, 33 Colo. 224, 80 Pac. 133 (1905). Some statutes make it manslaughter. State v. Dagartz, 244 Mo. 218, 148 S. W. 889 (1912). By some it is made a distinct felony. Montgomery v. State, 80 Ind. 338 (1881).

219. It will also avoid the need of speaking in terms of mitigation in certain manslaughter cases in which no such element is present. If there was an unlawful intent to kill, it is necessary to find some element of mitigation to prevent the crime from being 
The phrase "malice aforethought," although it has been reasonably stable from day to day, has shifted its moorings appreciably during the centuries, and gives today no assurance that the period of change has passed. With its present import, it is rather a bit of juridical shorthand than an explanatory expression. It is not a key which unlocks mysteries, but a label to be attached after the secret is solved. It has no magical powers. It is not a rule of thumb which can dispense with a rigid scrutiny of the facts of each particular case. It is, however, a convenient symbol. The psychical element of the crime of murder is so complex and complicated that legal discussions would be greatly handicapped if there were no term to express it. Had none been handed down by the ancients, it is quite probable that one would be created even if it were in the form familiar to science, such, perhaps, as "state of mind $A$." If no more than this is demanded of the phrase "malice aforethought," it has a very important function to perform.

murder. Hence it is very proper to speak in terms of mitigation if the killing was in the sudden heat of passion engendered by great provocation. But if the homicide is manslaughter because it resulted from culpable negligence it is quite unsound to speak of such negligence as an element of mitigation. Culpable negligence is an aggravating factor rather than a mitigating one, but the homicide is not murder because there was no man-endangering-state-of-mind. There was a man-endangering act but only a criminally negligent state of mind. 